\title{
Een nieuwe kijk op het werk en de loopbaan van jonge werknemers
}

\author{
Jos Akkermans, Veerle Brenninkmeijer \& Roland W.B. Blonk ${ }^{*}$
}

\begin{abstract}
In dit artikel geven we een overzicht van ons onderzoek naar het welzijn en de loopbaanontwikkeling van jonge werknemers die de transitie naar de arbeidsmarkt gaan maken of recent gemaakt hebben. We bespreken onze bevindingen op het gebied van werkkenmerken die belangrijk zijn voor jongeren om hen goed te laten functioneren en we gaan in op de loopbaancompetenties die ze nodig hebben om een goede start te geven aan hun werkende leven. Daarbij laten we zien dat juist de integratie tussen welzijn en loopbaanontwikkeling een belangrijk aandachtspunt is bij deze jonge werknemers. In dit promotieonderzoek zijn bovendien twee concrete instrumenten ontwikkeld en empirisch getoetst: de Career Competencies Questionnaire (CCQ) en de CareerSKILLS interventie. We bespreken deze instrumenten en geven aanbevelingen voor toekomstig onderzoek en de praktijk.
\end{abstract}

\section{$1 \quad$ Inleiding}

Op de huidige dynamische arbeidsmarkt is het voor werknemers steeds belangrijker om zelf de verantwoordelijkheid te nemen voor het vormgeven van hun werk en loopbaan (Segers \& Inceoglu, 2012). Door een toenemende druk op flexibiliteit en verandering wordt de traditionele loopbaan, die gekarakteriseerd wordt door voorspelbaarheid en verticale groei binnen een organisatie, steeds meer vervangen door de 'nieuwe loopbaan'. Daar waar de traditionele loopbaan gericht was op 'lifetime employment' en voorspelbaarheid, wordt de nieuwe loopbaan gekarakteriseerd door meer arbeidstransities, onvoorspelbaarheid en proactief zelfmanagement. Zo spreken Arthur, Khapova en Wilderom (2005) in dit verband van de boundaryless career, een loopbaan waarin werknemers zelf het initiatief dienen te nemen om flexibel en inzetbaar ('employable') te zijn. Hall en Moss (1998) spreken over de protean career, waarbij het voornaamste doel van het individu is om zichzelf optimaal te ontplooien. De conclusie is dat werknemers op een proactieve wijze hun eigen loopbaan zullen moeten vormgeven als zij succesvol willen zijn op de huidige arbeidsmarkt.

Werknemers worden niet alleen geconfronteerd met werkomgevingen die steeds dynamischer zijn, ook hun loopbanen worden in hun geheel complexer en langer, waardoor de uitdaging om gezond en gemotiveerd te blijven én succesvol te zijn

* Jos Akkermans is nu verbonden aan de Vrije Universiteit Amsterdam. Dit artikel is gebaseerd op een proefschrift dat gerealiseerd werd aan de Universiteit Utrecht. Correspondentieadres: Vrije Universiteit Amsterdam, Faculteit FEWEB, Afdeling Management en Organisatie, De Boelelaan 1105, 1081 HV Amsterdam, tel. 020-5982256. E-mail: j.akkermans@vu.nl. Veerle Brenninkmeijer is verbonden aan de Universiteit Utrecht. Roland W.B. Blonk is verbonden aan TNO. 
steeds groter wordt (Vuori, Toppinen-Tanner \& Mutanen, 2011). Dit lijkt in het bijzonder het geval voor jonge werknemers die nog aan het begin van hun loopbaan staan en daardoor weinig bagage hebben om met deze uitdagingen om te gaan. De laatste jaren is duidelijk te zien dat juist jonge werknemers het moeilijk hebben op de arbeidsmarkt: de gemiddelde jeugdwerkeloosheid in de Europese Unie lag in 2013 op 28\%, terwijl de algemene werkeloosheid op 11\% lag (Eurostat, 2013). Bovendien laat onderzoek zien dat jongeren die de arbeidsmarkt betreden in economisch zware tijden, zoals de wereldwijde recessie van de afgelopen jaren, een grotere kans hebben op een job mismatch en onderbenutting (Kahn, 2010). Het is bekend dat de zogenoemde school-naar-werk-transitie voor veel jongvolwassenen een moeilijke periode is: jongeren ervaren vaak ongunstige werkomstandigheden en onderbenutting (Koivisto, Vuori \& Nykyri, 2007) en ze ondergaan veel fundamentele veranderingen in een korte periode, zoals het ontwikkelen van een professionele identiteit (McKee-Ryan, Song, Wanberg \& Kinicki, 2005), het vinden van passend werk (Scherer, 2004) en het voltooien van hun eerste belangrijke socialisatieperiode (het proces waarbij nieuwkomers de transitie maken van outsiders naar insiders in een organisatie) (Bauer, Bodner, Erdogan, Truxillo \& Tucker, 2007; Koivisto et al., 2007). Onderzoek heeft bovendien aangetoond dat deze periode zeer stressvol kan zijn voor jonge werknemers en dat ze als gevolg hiervan minder gemotiveerd en bevlogen zijn dan oudere werknemers (Koivisto et al., 2007; Schaufeli \& Bakker, 2004).

Door de toenemende nadruk op proactiviteit en zelfsturing (Segers \& Inceoglu, 2012), de toenemende diploma-eisen op de arbeidsmarkt (Nieuwenhuis, Coenen, Fouarge, Harms \& Oosterling, 2012) en de groeiende complexiteit van loopbanen (Vuori et al., 2011), is het aannemelijk dat met name middelbaar en lager opgeleide jongeren problemen ervaren bij de start van hun loopbaan. De cijfers ondersteunen dit: lager opgeleide jongeren doen er gemiddeld dubbel zo lang (10 maanden) over om hun eerste baan te vinden, en van de groep lager opgeleide jongeren heeft vijf jaar na het betreden van de arbeidsmarkt slechts $45 \%$ betaald werk, tegenover $84 \%$ van de hoger opgeleiden (zie Akkermans, Nykänen \& Vuori, 2015b). Bovendien worden lager opgeleide jongeren vaker geconfronteerd met minder gunstige arbeidsomstandigheden, fysiek zwaarder werk en minder kansen op promoties en groei, waardoor ze een lagere kwaliteit van hun werk en loopbaan ervaren en ook hogere verzuimcijfers laten zien (European Commission, 2012; Smulders, 2005).

Gegeven de hierboven beschreven ontwikkelingen is het van groot belang dat jongvolwassenen de transitie van school naar werk op een succesvolle manier doorlopen, en daarbij een sterke start met hun loopbaan maken. Kennis over wat zij hiervoor nodig hebben, is echter nog beperkt. Zo heeft onderzoek wel predictoren aangewezen voor een succesvolle start, maar het heeft dat nog nauwelijks gedaan in de context van de 'nieuwe loopbaan' (Akkermans et al., 2015b). Dit is echter wel noodzakelijk, aangezien jonge werknemers veel meer dan voorheen zélf de regie moeten voeren over hun werk en loopbaan. De centrale onderzoeksvraag van ons onderzoek (Akkermans, 2013) luidt daarom: Welke factoren voorspellen een succesvolle start van de loopbaan van jonge werknemers in termen van welzijn en prestaties enerzijds, en hun loopbaancompetenties en inzetbaarheid anderzijds? 
Daarbij hebben we ons eerst gericht op taakkenmerken die het welzijn en de prestaties van jonge werknemers beïnvloeden (studie 1 en 2). Vervolgens hebben we gekeken naar loopbaancompetenties - dat wil zeggen kennis en vaardigheden die aan de basis staan van loopbaanontwikkeling en die ontwikkeld kunnen worden door het individu - die jongeren nodig hebben voor een succesvolle start (studie 3). Ook hebben we onderzocht hoe taakkenmerken en loopbaancompetenties in onderling samenspel een relatie hebben met het welzijn van jonge werknemers, om inzicht te krijgen in de samenhang tussen hun werk en loopbaan (studie 4). Tot slot hebben we een interventie ontwikkeld en empirisch getoetst die jongeren ondersteunt in de ontwikkeling van hun loopbaancompetenties en inzetbaarheid (studie 5).

\section{De rol van werkkenmerken in welzijn en prestaties van jonge werknemers}

In een relatief korte periode krijgen jonge werknemers allerlei nieuwe verantwoordelijkheden en rollen, moeten ze proactief en flexibel zijn, en wordt van hen verwacht dat ze zelfsturend zijn in hun werk en loopbaanontwikkeling (McKeeRyan et al., 2005; Ryan, 2001). Tegelijkertijd heeft deze nieuwe generatie werknemers haar eigen unieke karakteristieken, waarbij verschillen ten opzichte van ouderen te zien zijn in werkgerelateerde waarden en attituden (bijv. verminderde betrokkenheid en tevredenheid) en in loopbaanervaringen (bijv. meer vertrekintenties en mobiliteit) (Lyons \& Kuron, 2014). Dit alles geeft aan dat jongeren een unieke doelgroep vormen die op hun eigen wijze vorm willen en moeten geven aan hun werk en loopbaan. Dit betekent ook dat het belangrijk is om meer kennis te verzamelen over manieren waarop werkgevers en jonge werknemers zelf het werk dusdanig kunnen inrichten dat zij een hoge mate van welzijn en gezondheid ervaren en tegelijkertijd goed kunnen presteren. De eerste twee studies in dit promotieonderzoek leveren hieraan een bijdrage door in een tweetal grootschalige empirische studies met behulp van het Job Demands-Resources (JD-R) model (Demerouti, Bakker, Nachreiner \& Schaufeli, 2001) te onderzoeken welke werkgerelateerde hulpbronnen ('job resources'; bijv. autonomie en sociale steun) en taakeisen ('job demands'; bijv. hoge werkbelasting en emotionele eisen) bepalend zijn in het stimuleren van welzijn, gezondheid en prestaties van jonge werknemers. Het JD-R model beschrijft twee centrale processen: hulpbronnen kunnen in een motivationeel proces leiden tot een hogere mate van bevlogenheid ('work engagement'), wat vervolgens kan leiden tot verbeterde prestaties en gezondheid (Schaufeli \& Bakker, 2004), terwijl taakeisen via een uitputtingsproces kunnen leiden tot een hogere mate van burnout en vervolgens tot verminderde prestaties en gezondheid. Bij het toetsen van dit model hebben we een vergelijking gemaakt tussen jongeren met verschillende opleidingsniveaus. We hebben hierbij gebruikgemaakt van de Nationale Enquête Arbeidsomstandigheden (Koppes, De Vroome \& Van den Bossche, 2010), een grootschalige vragenlijst die jaarlijks wordt afgenomen door kennisinstituut TNO, het Centraal Bureau voor de Statistiek (CBS) en het ministerie van Sociale Zaken en Werkgelegenheid (SZW). De eerste studie was een cross-sectionele meting onder 2.535 jonge werknemers (Akkermans, 
Brenninkmeijer, Blonk \& Koppes, 2009), waarbij we regressieanalyses hebben gebruikt om ons model te toetsen en one-way ANOVA's met post-hoc tests om te kijken naar opleidingsverschillen. De tweede studie was een longitudinale meting op basis van twee meetmomenten met een tussenperiode van een jaar onder 1.284 jonge werknemers (Akkermans, Brenninkmeijer, Van den Bossche, Blonk \& Schaufeli, 2013b), waarbij we Structural Equation Modeling (SEM) analyses hebben gebruikt voor de modeltoets en MANOVA's om te kijken naar opleidingsverschillen.

\subsection{De voorspellende rol van hulpbronnen en stressoren}

De resultaten ondersteunen duidelijk het motivationele proces van het JD-R model. Een hogere mate van autonomie en sociale steun van collega's en leidinggevenden bleek positief samen te hangen met tevredenheid en toewijding op het werk, wat vervolgens positief samenhing met gezondheid en prestaties. Het tweede onderzoek liet zien dat deze relaties ook longitudinaal aanwezig zijn. We vonden echter gemengde resultaten met betrekking tot het uitputtingsproces: een hoge werkdruk en hoge emotionele eisen hingen positief samen met emotionele uitputting, maar ondersteuning voor het indirecte effect van taakeisen op gezondheid en prestaties via emotionele uitputting werd niet gevonden. Een verrassend resultaat was dat taakvariatie, in de regel beschouwd als hulpbron, negatief samen bleek te hangen met prestaties. Wellicht hebben jonge werknemers nog niet voldoende competenties opgebouwd in hun werk, waardoor een teveel aan taakvariatie ten koste gaat van hun prestaties (zie ook Goodwin \& O'Connor, 2007). Bovendien bleken mentale taakeisen, in de regel beschouwd als stressor, niet samen te hangen met emotionele uitputting en juist positief met tevredenheid op het werk. Een verklaring hiervoor kan zijn dat jongeren deze mentale taakeisen als een uitdaging beschouwen (Crawford, LePine \& Rich, 2010). Een derde verrassend resultaat was dat sociale steun van collega's een belangrijkere factor bleek in het motivatieproces dan sociale steun van de leidinggevende, terwijl de meeste studies tot nu toe het tegenovergestelde aantonen (bijv. Ouweneel, Taris, Van Zolingen \& Schreurs, 2009). Wellicht zijn deze jongeren extra gevoelig voor de invloed van leeftijdsgenoten, zoals dat ook in de adolescentie het geval is (Maxwell, 2002). Deze resultaten laten zien dat de basisprincipes van het JD-R model van toepassing zijn op jonge werknemers, maar dat er unieke factoren en processen zijn die hun welzijn en prestaties bepalen. Bovendien tonen deze studies aan dat uitputtingsprocessen onder jonge werknemers een minder grote rol blijken te spelen dan motivationele processen. Met andere woorden: jonge werknemers zullen niet snel uit het veld geslagen worden door de taakeisen in hun werk, en ze komen juist tot bloei als ze voldoende hulpbronnen ervaren.

\subsection{Verschillen tussen opleidingsniveaus}

Binnen de groep jonge werknemers vonden we duidelijke verschillen tussen opleidingsniveaus. Een eerste belangrijke resultaat was dat lager opgeleide (mbo niveau 1 , middelbaar onderwijs of geen afgerond onderwijs) en middelbaar opgeleide (mbo niveau 2, 3 en 4) jongeren nauwelijks van elkaar verschilden. Om die reden werden deze groepen in de tweede studie samengevoegd tot één groep. 
Deze groep verschilde echter op vrijwel alle studievariabelen van de hoger opgeleide jongeren. Ze gaven aan minder hulpbronnen, minder toewijding, een slechtere gezondheid en meer fysieke taakeisen te ervaren. Bovendien liet studie 2 zien dat lager en middelbaar opgeleide jongeren meer emotionele uitputting en minder goede prestaties rapporteerden. Deze bevindingen zijn in overeenstemming met studies over de Europese arbeidsmarkt (European Commission, 2012; Raad voor Werk en Inkomen, 2011) en met de zogenoemde 'social class gradient' (Borg \& Kristensen, 2000), in de zin dat individuen in lagere sociale klassen over het algemeen minder gunstige arbeidsomstandigheden en een lagere mate van welzijn en gezondheid ervaren.

Ook de test van het JD-R model resulteerde in verschillen tussen de twee opleidingsgroepen. Hoewel eerdere studies de robuustheid van het model in verschillende groepen en contexten hebben aangetoond (bijv. Korunka, Kubicek, Schaufeli \& Hoonakker, 2009), vonden we dat de relaties in het uitputtingsproces minder sterk waren bij de groep lager en middelbaar opgeleiden. Omdat het motivatieproces wel duidelijk overeind blijft, is het voor deze groep dus extra belangrijk dat zowel organisaties als de werknemers zelf voldoende hulpbronnen en ondersteuning proberen te creëren in het werk. Een interessante bevinding in de groep lager en middelbaar opgeleiden was bovendien dat er een wederkerige relatie bleek te zijn tussen toewijding en prestatie. Dit wijst op een mogelijke opwaartse spiraal, waarbij toewijding en prestatie elkaar kunnen versterken. Een vergelijkbare relatie, maar dan wederkerig verzwakkend, werd gevonden tussen emotionele uitputting en prestaties. Voor lager en middelbaar opgeleiden blijkt het dus van groot belang dat zij het gevoel hebben dat ze goed presteren, omdat een gebrek hieraan een negatief effect kan hebben op hun welzijn. Deze bevindingen sluiten aan bij de Conservation of Resources (COR) theorie (Hobfoll, 1989), die stelt dat hulpbronnen elkaar actief kunnen versterken en dat een tekort aan hulpbronnen zelfs kan leiden tot wederkerige verzwakking. Het toont ook aan dat we onderzoeken naar werkgerelateerd welzijn als een proces dienen te beschouwen dat meerdere richtingen uit kan gaan. Het is daarom belangrijk dat onderzoekers zowel oorzakelijke als wederkerige relaties tussen hulpbronnen en werkgerelateerd welzijn bestuderen, en daarbij aandacht besteden aan ontwikkelingen in de tijd (De Lange, De Witte \& Notelaers, 2008).

Met betrekking tot de centrale onderzoeksvraag laten studie 1 en 2 zien dat de aanwezigheid van hulpbronnen cruciaal is voor jonge werknemers (zie ook Figuur 1 en 2). Als zij autonomie, sociale steun en ontwikkelingsmogelijkheden ervaren, versterkt dit hun welzijn, gezondheid en prestaties. De aanwezigheid van stressoren, zoals een hoge emotionele en/of fysieke belasting, heeft een minder sterke samenhang met deze uitkomsten. Verder bleek dat lager opgeleide jongeren minder hulpbronnen ervaren dan hoger opgeleide jongeren, terwijl deze juist bij hen een positieve cyclus in gang kunnen zetten. 


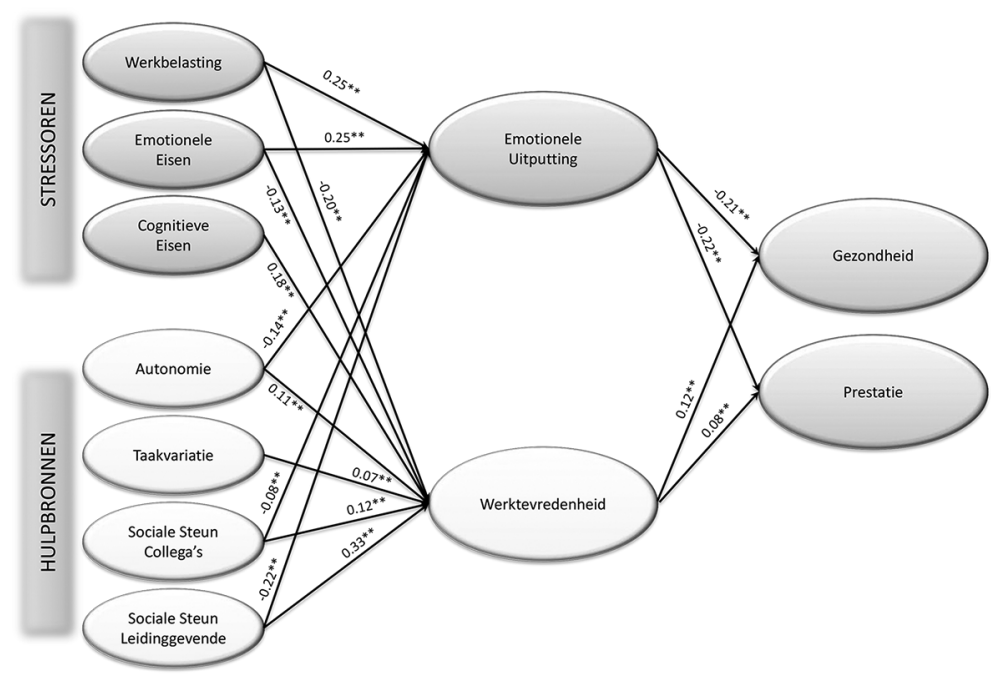

NB Niet-significante resultaten zijn niet weergegeven in het model. De indirecte effecten in het uitputtingsproces waren alle niet significant; de indirecte effecten in het motivatieproces waren significant voor beide vormen van sociale steun naar gezondheid, en voor autonomie en sociale steun van collega's naar prestatie. ${ }^{* *} p<.01$.

\section{Figuur 1 Onderzoeksresultaten van Studie 1}

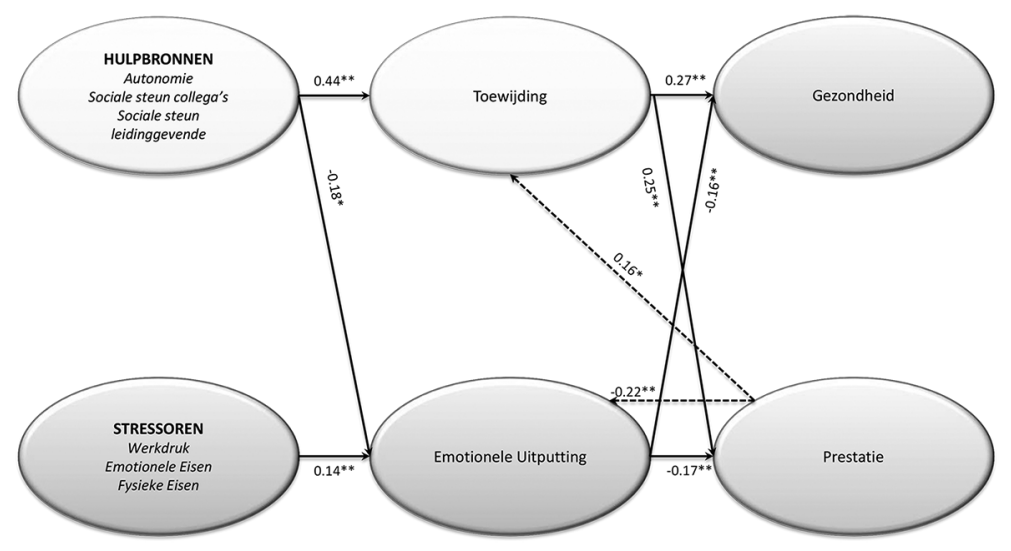

NB Alle variabelen zijn gemeten op T1 en T2; verbanden zijn steeds van T1 naar T2 (bijv. toewijding T1 naar prestatie T2; prestatie T1 naar toewijding T2). Niet-significante resultaten zijn niet weergegeven in het model. Indirecte effecten waren significant voor beide processen. De resultaten zijn gebaseerd op de groep lager en middelbaar opgeleide werknemers. Model voor hoger opgeleide groep kan opgevraagd worden bij de eerste auteur. ${ }^{* *} p<.01 ;^{*} p<.05$.

\section{Figuur 2 Onderzoeksresultaten van Studie 2}




\section{Het conceptualiseren en meten van loopbaancompetenties}

Meer kennis verzamelen over factoren die het welzijn en de prestaties van jonge werknemers verbeteren is stap één om een goede basis te leggen voor een sterke start van hun werkende leven. Werk en loopbaan zijn door de toenemende mate van zelfsturing, flexibiliteit en mobiliteit (Arnold \& Cohen, 2008) echter niet meer los van elkaar te zien. Jongeren hebben daardoor ook loopbaancompetenties nodig voor een succesvolle start. Loopbaancompetenties zijn ontwikkelbare kennis en vaardigheden op het niveau van de loopbaan en zijn daarmee te onderscheiden van werkcompetenties (competenties die nodig zijn om een baan goed uit te voeren) en leercompetenties (competenties die nodig zijn om nieuwe vaardigheden en kennis te vergaren) (Kuijpers \& Scheerens, 2006).

\subsection{Wetenschappelijke achtergrond van loopbaancompetenties}

Sinds de jaren negentig van de vorige eeuw wordt er onderzoek gedaan naar loopbaancompetenties. Zo formuleerden Defillippi en Arthur (1994) de 'knowing why' (bijv. loopbaaninzicht), 'knowing whom' (bijv. professionele netwerken) en 'knowing how' (bijv. professionele activiteiten) competenties binnen hun perspectief van de boundaryless career. Rond dezelfde periode formuleerden Mirvis en Hall (1994) hun visie op de protean career. Anakwe, Hall en Schor (2000) onderscheidden hierbij drie typen loopbaancompetenties: 'self-knowledge skills' (bijv. zelfbewustzijn), 'interpersonal knowledge skills' (bijv. assertiviteit) en 'environmental knowledge skills' (bijv. bewust zijn van kansen). Een derde perspectief van waaruit onderzoek is gedaan naar loopbaancompetenties is career self-management. Een voorbeeld is de studie van De Vos, De Clippeleer en Dewilde (2009), die een tweetal componenten benoemden voor effectief zelfmanagement: de gedragsmatige component (bijv. doelen stellen) en de cognitieve component (bijv. reflectieve vaardigheden). Het vierde en laatste perspectief is het human capital perspectief van Kuijpers (2003). Zij onderscheidde in haar werk diverse loopbaancompetenties die werknemers nodig hebben om inzetbaar te worden. Zo benoemden Kuijpers, Meijers en Gundy (2011) drie typen competenties: reflectieve gedragingen (bijv. loopbaanreflectie), proactieve gedragingen (bijv. werkverkenning) en interactieve gedragingen (bijv. netwerken).

Onderzoek naar loopbaancompetenties toont aan dat loopbaancompetenties een positief effect kunnen hebben op onder andere loopbaansucces (Kuijpers, Schyns \& Scheerens, 2006), werknemerstevredenheid en betrokkenheid (Colakoglu, 2011; Kong, 2013) en inzetbaarheid (Mayotte, 2003). De verschillende perspectieven in de literatuur hebben echter andere uitgangspunten van waaruit ze loopbaancompetenties conceptualiseren. Daardoor was er tot op heden nog geen eenduidige omschrijving van loopbaancompetenties. Om die reden hebben we een 'mixed-method' studie uitgevoerd onder middelbaar opgeleide jongeren, bestaande uit zowel kwalitatief als kwantitatief onderzoek, met als doel een integratief theoretisch kader te ontwikkelen voor loopbaancompetenties (Akkermans, Brenninkmeijer, Huibers \& Blonk, 2013a). Dit heeft geleid tot de ontwikkeling en validering van een nieuwe vragenlijst voor het meten van loopbaancompetenties. 


\subsection{De ontwikkeling van de Career Competencies Questionnaire}

Op basis van een literatuur review en op basis van interviews met diverse stakeholders (bijv. HR managers, opleidingsmanagers, wetenschappers, vakbonden) ( $N$ $=22)$ en focusgroepen met middelbaar opgeleide jongeren $(N=43)$ werd een eerste theoretisch kader geformuleerd. Allereerst werd de bestaande literatuur geanalyseerd, waaruit bleek dat loopbaancompetenties in te delen zijn in drie dimensies: reflectieve loopbaancompetenties, communicatieve loopbaancompetenties en gedragsmatige loopbaancompetenties. Op basis van de resultaten van de interviews en focusgroepen is vervolgens een selectie gemaakt van de belangrijkste loopbaancompetenties voor jonge werknemers. Daaruit bleek dat elke dimensie bestond uit twee competenties. Reflectieve loopbaancompetenties omvatten reflectie op motivatie, oftewel het reflecteren op waarden, passies en motivatie met betrekking tot de loopbaan, en reflectie op kwaliteiten, wat zich richt op sterke punten en ontwikkelpunten in het kader van de eigen loopbaan. De communicatieve competenties zijn netwerken, dus het bewust zijn en kunnen uitbreiden van het persoonlijke en professionele netwerk, en zelfprofilering, dat gaat over het vermogen om kennis en vaardigheden naar de interne en externe arbeidsmarkt te kunnen communiceren. Tot slot bestaan gedragsmatige competenties uit werkexploratie, het proactief zoeken naar mogelijkheden op de interne en externe arbeidsmarkt, en loopbaansturing, oftewel het actief beïnvloeden van leerprocessen en werkprocessen gerelateerd aan de loopbaan door het opstellen en behalen van plannen en doelen.

Op basis van dit model werd een eerste versie van de Career Competencies Questionnaire (CCQ) ontwikkeld. Met behulp van twee kwantitatieve studies werd de CCQ ingekort en empirisch getoetst op betrouwbaarheid en validiteit. Een exploratieve factoranalyse op basis van de gegevens van 219 middelbaar opgeleide jongvolwassenen en een confirmatieve factoranalyse op basis van SEM-analyses op een tweede sample van 212 middelbaar opgeleide jongvolwassenen ondersteunde zowel de inhoudsvaliditeit, de factoriële validiteit, de discriminante validiteit als de incrementele validiteit van de CCQ. De incrementele validiteit werd getoetst in een regressiemodel, waarbij we aantoonden dat loopbaancompetenties aanvullende voorspellende waarde hadden als antecedent van waargenomen inzetbaarheid (De Cuyper \& De Witte, 2008) bovenop de gerelateerde factoren self-efficacy (Bandura, 1997), prestatie (Goodman \& Svyantek, 1999) en loopbaanmotivatie (Day \& Allen, 2004). Loopbaancompetenties bleken daarbij positief samen te hangen met al deze factoren (correlaties variërend van .32 tot .41). Tot slot vormden de 21 items een betrouwbare manier om de zes competenties te meten. De items van de CCQ zijn te vinden in bijlage 1.

Studie 3 (zie ook Figuur 3) draagt bij aan de beantwoording van de centrale onderzoeksvraag door een integratief theoretisch kader te presenteren van loopbaancompetenties die middelbaar opgeleide jongeren nodig hebben voor een succesvolle start van hun loopbaan. Hierbij blijken vooral reflectieve, communicatieve en gedragsmatige competenties van belang. Om deze loopbaancompetenties op betrouwbare en valide wijze te meten is de Career Competencies Questionnaire ontwikkeld. 


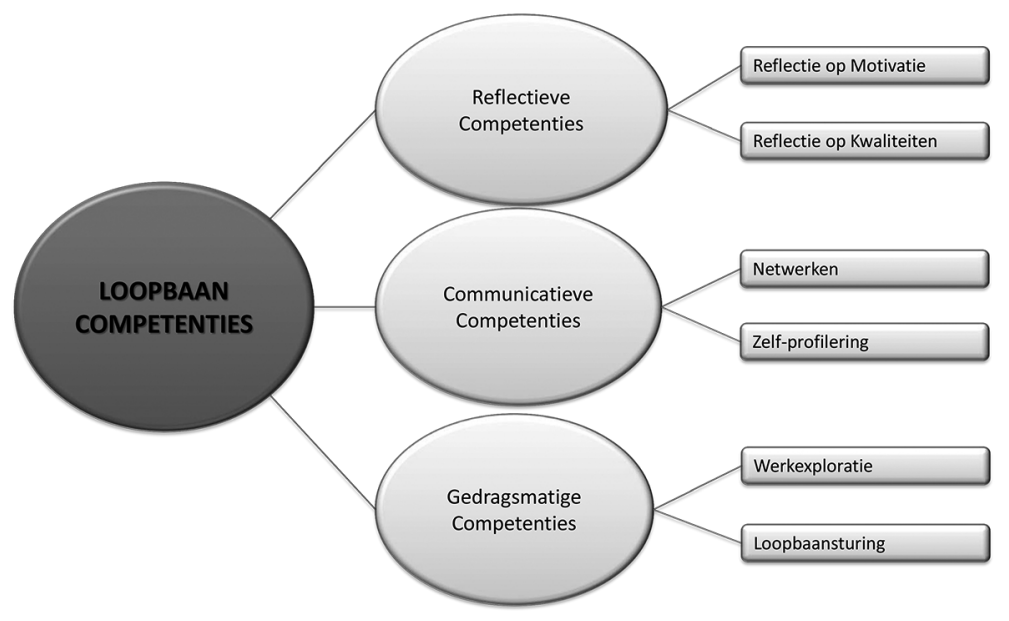

Figuur 3 Onderzoeksresultaten van Studie 3: integratief theoretisch kader van loopbaancompetenties

\section{Integreren van bevindingen over welzijn en loopbaancompetenties}

De volgende stap in dit promotieonderzoek was een brug te slaan tussen onderzoek naar werkgerelateerde factoren (het welzijn van werknemers; studie 1 en 2) en loopbaangerelateerde factoren (loopbaancompetenties; studie 3), een doel waarvan het belang ook al onder de aandacht werd gebracht door Hall en Las Heras (2010). In de vierde studie (Akkermans, Schaufeli, Brenninkmeijer \& Blonk, 2013c) brachten we de inzichten uit de eerste drie studies samen door te kijken naar de rol van loopbaancompetenties in het welzijn van jonge werknemers. Hierbij werden jongeren van diverse opleidingsgroepen betrokken om het theoretische kader van loopbaancompetenties te kunnen generaliseren naar jonge werknemers in algemene zin. Onze verwachting was dat loopbaancompetenties een soortgelijke rol zouden hebben als persoonlijke hulpbronnen (bijvoorbeeld optimisme en zelfvertrouwen; Xanthopoulou, Bakker, Demerouti \& Schaufeli, 2009) in het stimuleren van bevlogenheid, zoals beschreven in het motivationele proces van het JD-R model, omdat loopbaancompetenties, net als persoonlijke hulpbronnen, gericht zijn op persoonlijke groei en het bereiken van doelen. Tegelijkertijd verwachtten we dat loopbaancompetenties geen rol zouden spelen in het bufferen van burnout. De redenering hierbij is dat loopbaancompetenties primair gericht zijn op motivatie en positieve zelf-evaluaties, wat in het bijzonder relevant is voor motivationele processen. Bovendien liet eerder onderzoek van Xanthopoulou, Bakker, Demerouti en Schaufeli (2007) zien dat persoonlijke hulpbronnen geen samenhang vertoonden met uitputtingsprocessen. We hebben dit cross-sectionele onderzoek uitgevoerd onder 305 jonge werknemers, waarbij we SEM-analyses met latente factoren hebben gebruikt om ons model te toetsen. 


\section{De rol van loopbaancompetenties in het JD-R model}

Loopbaancompetenties bleken significant positief samen te hangen met werkgerelateerde hulpbronnen en met bevlogenheid. We vonden bovendien significante mediatie-effecten: loopbaancompetenties medieerden de positieve relatie tussen hulpbronnen (autonomie, sociale steun en ontwikkelingsmogelijkheden) en bevlogenheid. Dat wil zeggen: jongeren die meer hulpbronnen ervaren, beschikken over meer loopbaancompetenties en voelen zich daardoor meer bevlogen. Andersom vonden we ook een mediatie-effect: jongeren die over meer loopbaancompetenties beschikken, ervaren (en genereren) meer hulpbronnen en voelen zich meer bevlogen. Vanwege het cross-sectionele karakter van onze studie konden we de exacte aard van deze relatie niet duiden, maar de resultaten wijzen erop dat werkgerelateerde hulpbronnen en loopbaancompetenties in onderling samenspel het welzijn van jonge werknemers kunnen verhogen. Dit kan wijzen op een zogenoemde resource caravan (Hobfoll, 2011), dat wil zeggen een zichzelf versterkend positief effect waarbij hulpbronnen weer nieuwe hulpbronnen genereren, en is daarmee in overstemming met de Conservation Of Resources (COR) theorie. Loopbaancompetenties bleken, zoals verwacht, niet samen te hangen met werkgerelateerde stressoren en emotionele uitputting. Hieruit concluderen we dat loopbaancompetenties enkel een rol spelen in motivationele processen en niet in uitputtingsprocessen. Dit sluit goed aan bij de bevindingen van de eerste twee studies, waar we ook vonden dat juist hulpbronnen en motivationele processen cruciaal zijn voor jonge werknemers. Alles bij elkaar genomen ontstaat er dus een beeld van jonge werknemers die goed om kunnen gaan met de taakeisen die ze in hun beginnende loopbaan tegenkomen en juist echt tot bloei komen als ze voldoende hulpbronnen ervaren en loopbaancompetenties ontwikkelen. Dat loopbaancompetenties een positieve rol kunnen spelen in het welzijn van jonge werknemers, ondersteunt de suggestie van Hall en Las Heras (2010) om onderzoek naar werkgerelateerde thema's en loopbaangerelateerde thema's meer te integreren.

De resultaten van studie 4 (zie ook Figuur 4) leveren een belangrijke bijdrage aan de centrale onderzoeksvraag door aan te tonen dat de aanwezige taakkenmerken van jonge werknemers in samenspel met de ontwikkeling van hun loopbaancompetenties een positieve samenhang hebben met hun bevlogenheid. Hiermee integreren we de resultaten uit de eerste drie studies en laten we zien dat het belangrijk is om werkgerelateerde en loopbaangerelateerde factoren in samenhang te bestuderen in onderzoek naar het functioneren van jonge werknemers.

\section{Het trainen van loopbaancompetenties via CareerSKILLS}

\subsection{Ontwikkeling en uitvoering van de CareerSKILLS-interventie}

Een laatste stap die binnen dit onderzoek is gemaakt, is om de nieuwe inzichten op het gebied van loopbaancompetenties te vertalen naar een kortdurende groepsinterventie. De basis voor deze interventie is de JOBS-methodiek (Caplan, Vinokur, Price \& Van Ryn, 1989). Het kenmerkende aan deze methodiek is haar 


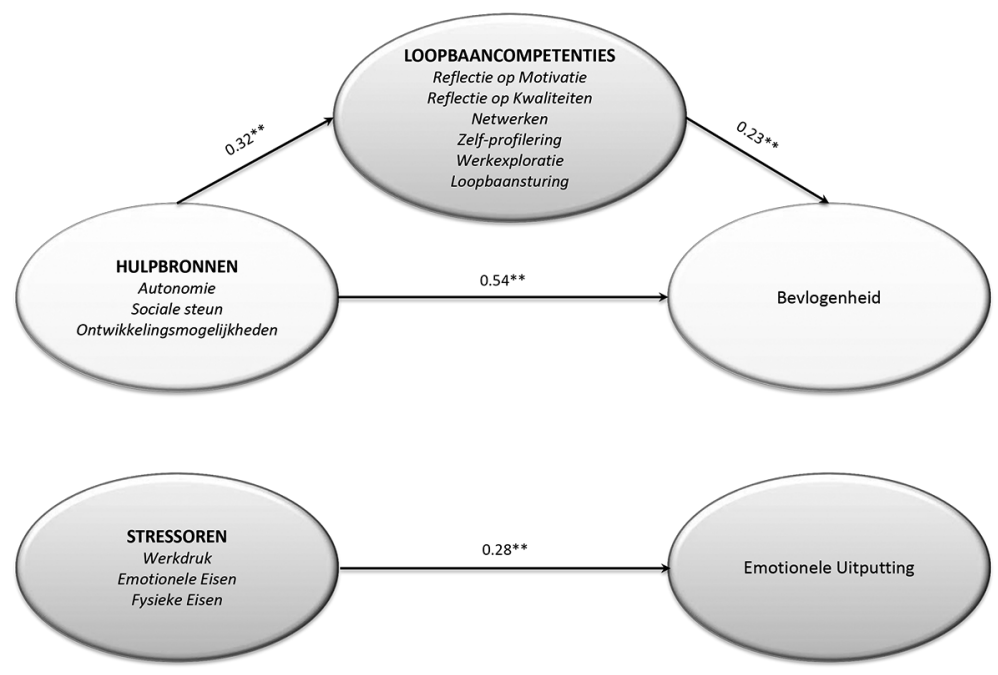

NB. Het gestandaardiseerde indirect verband van hulpbronnen naar bevlogenheid was significant $(\beta=.08, \mathrm{p}<.001,95 \%$ CI $[.03, .13]$. Het model met hulpbronnen als mediator tussen loopbaancompetenties en bevlogenheid gaf ook een significant indirect effect $(\beta=.17, \mathrm{p}<.001,95 \%$ CI [.09, .27]. ${ }^{* *} p<.01$.

\section{Figuur 4 Onderzoeksresultaten van Studie 4}

positieve focus op het versterken van self-efficacy (vertrouwen in het eigen kunnen; Bandura, 1997) en het om kunnen gaan met obstakels (Meichenbaum, 1985). Er is inmiddels in verschillende landen, waaronder de VS, Finland en Nederland, empirische evidentie voor de effectiviteit van deze methodiek (Brenninkmeijer \& Blonk, 2011; Vinokur, Price \& Schul, 1995; Vuori et al., 2011). Op basis van deze methode en op basis van de bevindingen uit de eerste vier studies is de CareerSKILLS-interventie ontwikkeld. Deze interventie richt zich op het versterken van de loopbaancompetenties binnen het theoretische kader van studie 3 en 4 . Sessie 1 richt zich bijvoorbeeld op reflectieve competenties met oefeningen over overdraagbare vaardigheden (reflectie op kwaliteiten) en het maken van een persoonlijk embleem (reflectie op motivatie en kwaliteiten). Andere voorbeelden van oefeningen zijn het tekenen van een netwerkkaart (netwerken), een rollenspel van een sollicitatiegesprek (zelf-profilering), het in kaart brengen van ontwikkelingsmogelijkheden (werkexploratie) en het opstellen van een loopbaanplan (loopbaansturing).

De CareerSKILLS-training werd geïmplementeerd in twee grote organisaties: een onderwijsinstelling (Ninterventie $=112$, Ncontrole $=61$ ) en een multinational (Ninterventie $=71$, Ncontrole $=41)$ (Akkermans, Brenninkmeijer, Schaufeli \& Blonk, 2015a). De onderwijsinstelling was de primaire toets voor effectiviteit, aangezien hier middelbaar opgeleide jongeren deelnamen. De multinational was een secundaire effectiviteitsmeting waarbij kruisvalidering van effectiviteit plaatsvond in een heterogene groep met ook hoger opgeleiden. De interventie 
bestond uit vier dagdelen van vier uur die binnen twee weken afgerond werden, gevolgd door een terugkomdag zes weken na de start. Deelnemers in de controlegroepen volgden hun reguliere onderwijscurriculum (onderwijsinstelling) en trainingsprogramma (multinational). Centraal in de interventie stonden actieve leerprocessen via oefeningen, brainstormsessies en rollenspelen die erop gericht waren de zes loopbaancompetenties te stimuleren bij de deelnemers. Daarbij was de methodiek specifiek gericht op het versterken van hun self-efficacy en het kunnen omgaan met obstakels. Een laatste doel van de interventie was om te kijken of een loopbaangerelateerde interventie als CareerSKILLS ook een effect zou kunnen hebben op het werkgerelateerde welzijn van deze jonge werknemers. Het volledige trainershandboek staat beschreven in Akkermans en Lagerveld (2010).

\subsection{Effectiviteit van de CareerSKILLS-interventie}

De empirische test op effectiviteit van de CareerSKILLS-interventie vond plaats op drie meetmomenten: een baselinemeting (T1) voorafgaand aan de eerste sessie, een tweede meting (T2) direct na het vierde dagdeel, en een derde meting (T3) direct na de terugkomdag. De controlegroepen werden vanwege praktische overwegingen enkel op T1 en T3 meegenomen in de dataverzameling. Om de effectiviteit te toetsen werden Multivariate Analyses of Variance (MANOVA's) gebruikt. Daarbij werd gekeken naar effecten van groep (interventie versus controle), tijd (T1 versus T2 versus T3) en het interactie-effect van Groep x Tijd (verschillende ontwikkeling per groep over de tijd). In de primaire doelgroep van middelbaar opgeleide jongvolwassenen vonden we dat deelnemers aan de interventie, ten opzichte van een controlegroep, hoger scoorden op hun loopbaancompetenties, hun self-efficacy en dat ze zich beter in staat voelden om obstakels te kunnen overwinnen na de interventie. Bovendien gaven ze aan meer loopbaangerelateerd gedrag te vertonen, zich meer inzetbaar te voelen en ook gemotiveerder te zijn om aan de slag te gaan met hun loopbaan. Tot slot vonden we dat deelnemers aan CareerSKILLS, ten opzichte van de controlegroepen, wél een toename ervoeren in hun werkbevlogenheid en geen verschil in hun emotionele uitputting. Vrijwel identieke resultaten kwamen naar voren in de secundaire effectmeting binnen de multinational. De resultaten lieten bovendien in beide samples zien dat het effect tussen T1 en T2 binnen de interventiegroepen stabiel bleef tot en met T3. De korte termijn effectiviteit van de CareerSKILLS-interventie is hiermee aangetoond. De bevindingen laten zien dat loopbaancompetenties beïnvloedbaar zijn via een interventie en dat de actieve leerprocessen, in combinatie met een focus op self-efficacy en weerbaarheid tegen obstakels, daar een goede basis voor zijn. Dit is in overeenstemming met bevindingen dat zelf-geïnitieerde leerprocessen en intrinsieke motivatie cruciaal zijn om jongvolwassenen te laten groeien en ontwikkelen (bijv. Ng, Sorensen \& Eby, 2006; Spector, Cooper, Sanchez, O’Driscoll \& Sparks, 2002). Hiermee wordt bovendien de effectiviteit van de JOBS-methodiek (Caplan et al., 1989) verder onderschreven en komen we ook tegemoet aan de oproep van Vuori et al. (2011) om meer empirische effectstudies uit te voeren voor loopbaangerelateerde interventies. Tot slot sluiten deze resultaten aan bij de eerdere studies in dit proefschrift door aan te tonen dat loopbaancompetenties 


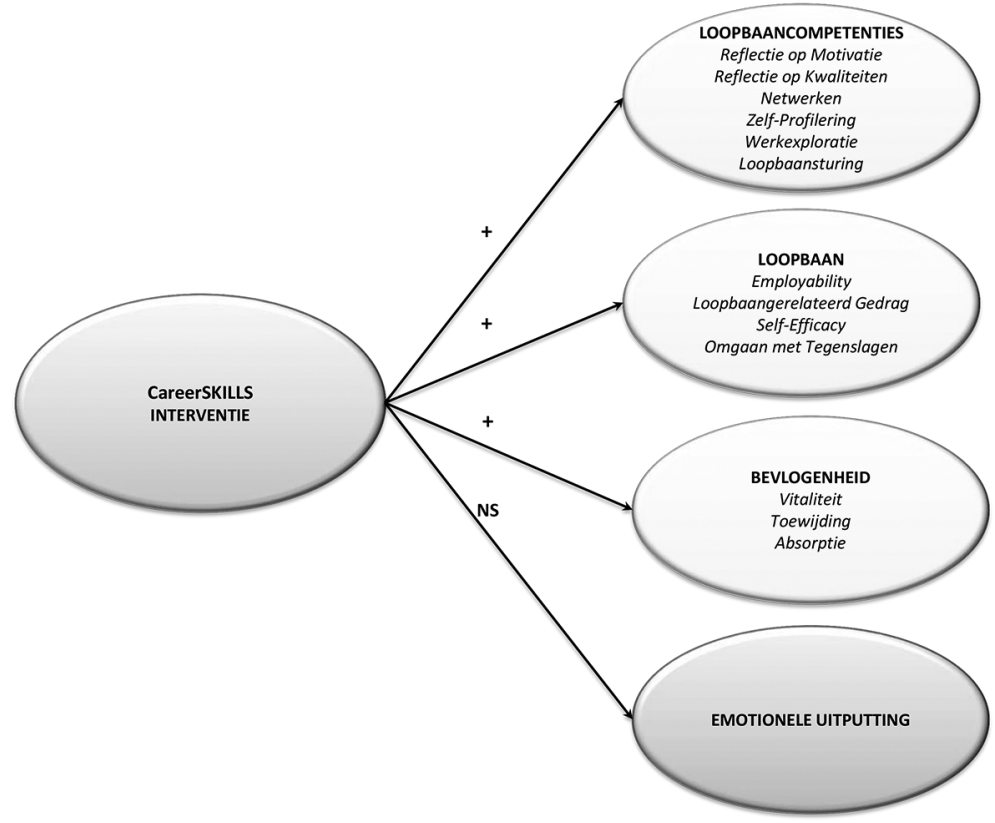

NB. Alle Tijd x Groep interactie-effecten waren significant op $p<.01$ in het voordeel van de interventiegroep. Voor emotionele uitputting werden geen effecten gevonden. Vrijwel alle gemiddelden bij de interventiegroep stegen tussen T1 en T2 en bleven vervolgens stabiel tot en met T3.

\section{Figur 5 Onderzoeksresultaten van Studie 5}

ook een rol spelen in het welzijn van jonge werknemers, dus dat het werk en de loopbaan van jonge werknemers nauw met elkaar samenhangen.

De resultaten in studie 5 (zie ook Figuur 5) dragen bij aan de beantwoording van de hoofdvraag door te laten zien dat loopbaancompetenties een belangrijke rol spelen in het verhogen van het welzijn en de loopbaanontwikkeling van jonge werknemers. Wederom wordt onderstreept dat het integreren van werk en loopbaan belangrijk is, aangezien het trainen van loopbaancompetenties samengaat met een verhoging van bevlogenheid (werk) en inzetbaarheid (loopbaan).

\section{Suggesties voor toekomstig onderzoek}

\subsection{Ontwerpen van 'smart jobs'}

De bevindingen in dit artikel laten een duidelijke samenhang tussen werkgerelateerde en loopbaangerelateerde factoren zien. Specifiek blijken loopbaancompetenties een rol te kunnen spelen in het stimuleren van bevlogenheid, in wisselwerking met aanwezige werkgerelateerde hulpbronnen. Hall en Las Heras (2010) beargumenteerden al dat onderzoek naar werkgerelateerde thema's en loopbaan- 
gerelateerde thema's meer geïntegreerd dient te worden en om daarmee onderzoek te doen naar zogenoemde 'smart jobs': banen waarin werknemers goed kunnen presteren, maar tegelijkertijd ook voortdurend kunnen leren en zich kunnen ontwikkelen. Ons onderzoek sluit daar nauw bij aan, aangezien loopbaancompetenties (een loopbaangerelateerd thema) nauw bleken samen te hangen met taakkenmerken en bevlogenheid (beide werkgerelateerde thema's). Toekomstig onderzoek onder jonge werknemers zou meer inzicht kunnen bieden in factoren die ten grondslag liggen aan deze smart jobs. Op het niveau van de organisatie is het bijvoorbeeld interessant om te kijken hoe banen zo ontworpen kunnen worden dat ze werknemers in staat stellen om goed te presteren en zich te ontwikkelen, en tegelijkertijd bij te dragen aan de productiviteit en het innovatief vermogen van een organisatie. Op het niveau van de individuele werknemers kan gekeken worden welke proactieve gedragingen zij kunnen uitvoeren om hun werk en loopbaan dusdanig vorm te geven dat ze er beter door gaan functioneren en zich tevens kunnen ontwikkelen. Een interessante onderzoeksrichting is om te kijken naar de samenhang tussen loopbaancompetenties en job crafting (Tims, Bakker \& Derks, 2013) en de rol daarvan in het ontwerpen van smart jobs. Bovendien zouden toekomstige studies kunnen kijken naar de rol van deze smart jobs in harde performance indicatoren (bijv. ziekteverzuim, productiviteit) en zachte performance indicatoren (bijv. duurzame inzetbaarheid, innovatie) van bedrijven.

\subsection{Verschillen tussen opleidingsgroepen en leeftijdsgroepen}

Er is meer onderzoek nodig om mogelijke verschillen tussen opleidingsgroepen en leeftijdsgroepen te bestuderen. Hoewel eerder onderzoek de robuustheid van het JD-R model heeft aangetoond, vonden wij verschillen in voorspellers van welzijn tussen lager en hoger opgeleide jongeren. Wellicht zijn deze verschillen gerelateerd aan een bepaalde optimale hoeveelheid hulpbronnen en stressoren in het werk, dat wil zeggen: mogelijk zijn er curvi-lineaire effecten aanwezig. Dit zou ook een mogelijke verklaring zijn voor de negatieve samenhang tussen taakvariatie en prestatie: variatie is goed, maar te veel werkt contraproductief. Zo toonde Polat (2015) aan dat werkdruk in beperkte mate een positief effect heeft op welzijn, maar in hoge mate juist een negatief effect. Het is mogelijk dat juist in deze curvilineaire effecten verschillen schuilen tussen opleidingsgroepen. Het is ook belangrijk om te kijken of ons theoretische model van loopbaancompetenties in het kader van de levensloop van toepassing is. Gerelateerd aan vraagstukken over duurzame inzetbaarheid van oudere werknemers zou de vraag gesteld kunnen worden of dezelfde zes competenties voor hen van belang zijn en of deze loopbaancompetenties wellicht juist zouden kunnen fungeren als een buffer tegen uitputting en burnout. Op basis van de Selection, Optimization, and Compensation (SOC) theorie (Baltes \& Baltes, 1990) zou dit laatste verwacht kunnen worden, omdat oudere werknemers niet meer zoveel aankunnen als voorheen en daardoor selectiever moeten zijn in de activiteiten die ze ondernemen om goed te blijven functioneren. Loopbaancompetenties zouden dan de input kunnen vormen voor de selectie en optimalisatie van activiteiten, waardoor oudere werknemers op niveau kunnen blijven presteren. 


\subsection{Theorievorming over de school-naar-werk-transitie}

In de afgelopen decennia zijn er talloze studies uitgevoerd die inzicht bieden in de factoren die voorspellend zijn voor een succesvolle school-naar-werk-transitie. Zoals Akkermans et al. (2015b) echter aangeven, wordt er in veel studies gewerkt met theoretische modellen die al lange tijd in omloop zijn, zoals het personalityjob fit model van Holland (1985). Door de vele veranderingen in de 'nieuwe loopbaan' (bijv. meer flexibiliteit en proactiviteit) is het de vraag of de traditionele modellen van loopbaanontwikkeling nog helemaal van toepassing zijn, temeer omdat de nieuwe generatie werknemers op de arbeidsmarkt haar eigen kenmerken, wensen en eisen heeft (Lyons \& Kuron, 2014). Onze bevindingen over de rol van loopbaancompetenties kunnen een eerste stap zijn naar nieuwe theorievorming. Hiervoor is het echter belangrijk om ook gerelateerde concepten in ogenschouw te nemen. Zo is er recent onderzoek gedaan naar career adaptability (Savickas, 2005), wat bestaat uit de dimensies 'career concern' (vooruit kijken naar de toekomst), 'career control' (bewuste beslissingen maken), 'career curiosity' (alternatieven bekijken) en 'career confidence' (vertrouwen op het eigen kunnen). Er is duidelijk overlap met het concept loopbaancompetenties, bijvoorbeeld dat beide concepten een dimensie 'career control' bevatten die gericht is op plannen en doelen nastreven. Een ander gerelateerd concept is het hierboven genoemde job crafting (Tims et al., 2013). Proactieve vormen van aanpassing en vormgeving ('crafting') kunnen ook plaatsvinden op het niveau van de loopbaan wanneer loopbaancompetenties tot daadwerkelijk proactief gedrag leiden. In die zin zou men kunnen spreken van career crafting. Toekomstig onderzoek zou kunnen verkennen in hoeverre deze concepten samenhangen en wat hun toegevoegde waarde is in theorievorming over een succesvolle school-naar-werk-transitie van jonge werknemers.

\section{Praktische implicaties}

Een eerste implicatie betreft de bevinding dat jonge werknemers relatief goed weerbaar zijn tegen aanwezige taakeisen (bijv. emotionele en fysieke belasting) en juist in sterke mate gestimuleerd worden door aanwezige hulpbronnen (bijv. autonomie en sociale steun). Te veel variatie in het werk blijkt contraproductief, terwijl uitdagende taken juist weer zorgen voor meer tevredenheid met het werk. Het is voor HR-managers en lijnmanagers dus belangrijk om deze unieke kenmerken van jonge werknemers in acht te nemen en daar hun werkomgeving waar mogelijk op aan te passen. Daarbij is het in het bijzonder belangrijk om ervoor te zorgen dat ze voldoende hulpbronnen aangeboden krijgen in hun werk en dat hun taken uitdagend, maar helder gestructureerd zijn. Tegelijkertijd dient een ondersteunend klimaat gerealiseerd te worden dat jonge werknemers in staat stelt om zelf het initiatief te nemen hun werk aan te passen met het oog op deze hulpbronnen (dus: hun baan te 'craften').

Een tweede praktische implicatie heeft betrekking op de bevinding dat loopbaancompetenties een belangrijke rol spelen in de loopbaanontwikkeling van jonge werknemers. Als jongeren werken aan hun reflectieve, communicatieve en 
gedragsmatige loopbaancompetenties worden ze meer inzetbaar, vertonen ze meer loopbaangerelateerd gedrag, krijgen ze meer vertrouwen in hun eigen kunnen en zijn ze ook weerbaarder tegen obstakels in hun werk en loopbaan. Het is dus belangrijk om zowel werkende als werkeloze jongeren te stimuleren om hun loopbaancompetenties te ontwikkelen. Werkende jongeren kunnen hiermee een sterke start van hun loopbaan realiseren en zich sneller ontwikkelen, terwijl werkeloze jongeren deze competenties kunnen ontwikkelen om proactiever en weerbaarder te worden, wat de kans vergroot dat zij een baan vinden.

Dit promotieonderzoek biedt bovendien twee concrete tools aan voor organisaties en werknemers in de vorm van de Career Competencies Questionnaire (CCQ) en de CareerSKILLS-interventie. Bedrijven, loopbaancoaches en onderwijsinstellingen zouden de CCQ op systematische wijze kunnen inzetten als monitoring tool onder jonge werknemers en jongeren die bijna de stap naar de arbeidsmarkt gaan maken. De CCQ zou daarmee een diagnostisch instrument kunnen zijn waarmee de ontwikkeling van reflectieve, communicatieve en gedragsmatige loopbaancompetenties vastgesteld kan worden, wat vervolgens kan dienen als input voor interventies. Bovendien zouden onderwijsinstellingen de CareerSKILLS-interventie in hun curriculum kunnen opnemen om jongeren voor te bereiden op de transitie naar hun werkende leven, en zouden bedrijven hun jonge werknemers deze interventie kunnen aanbieden als onderdeel van hun HR-beleid. Hiermee kunnen de CCQ en CareerSKILLS-tools dienen als basis voor een duurzaam inzetbare groep jonge werknemers, die op hun beurt bijdragen aan de productiviteit en innovatie van bedrijven.

Een vierde implicatie voor de praktijk is dat het voor organisaties aan te raden is hun beleid omtrent 'performance management' en 'job design' meer te integreren met beleid op het gebied van (loopbaan)ontwikkeling van hun werknemers. Ons onderzoek laat zien dat loopbaancompetenties en aanwezige hulpbronnen gezamenlijk kunnen zorgen voor een toename in bevlogenheid, en dat de thema's werk en loopbaan dus nauw aan elkaar gerelateerd zijn. De sleutel naar zogenoemde 'smart jobs', banen waarin werknemers productief zijn en zich tegelijkertijd voortdurend ontwikkelen, is om HR 'practices' omtrent het versterken van welzijn en loopbaanontwikkeling meer te integreren. Organisaties zouden bijvoorbeeld de CareerSKILLS-interventie als opleidingsmogelijkheid kunnen opnemen en tegelijkertijd werknemers de mogelijkheid kunnen bieden om hun job proactief aan te passen. De CCQ kan hierbij een tool zijn die aanknopingspunten biedt voor concrete vervolgstappen.

\section{Conclusie}

Jongeren ervaren veel unieke uitdagingen tijdens de start van hun loopbaan, die ervoor kunnen zorgen dat ze op jonge leeftijd al verlaagde arbeidskansen en verminderd welzijn ervaren. Dit promotieonderzoek biedt inzicht in de werkkenmerken en loopbaancompetenties die van belang zijn voor jongvolwassenen tijdens de start van de loopbaan. Bovendien zijn er twee concrete tools ontwikkeld die gebruikt kunnen worden om loopbaancompetenties te meten en te stimuleren: de 
Career Competencies Questionnaire (CCQ) en de CareerSKILLS-interventie. We gaan ervan uit dat deze bevindingen, de praktische implicaties van die bevindingen en onze suggesties voor toekomstig onderzoek zullen leiden tot een nieuwe impuls in onderzoek naar, en ondersteuning van, jonge werknemers die aan de start staan van hun loopbaan. Als dat gebeurt, kunnen we een sterke basis realiseren voor een duurzaam inzetbare beroepsbevolking met jonge werknemers die proactief hun werk en loopbaan managen en daar ook op lange termijn profijt van zullen hebben.

Praktijkbox

Wat betekenen de resultaten voor de praktijk?

- HR-afdelingen van bedrijven zouden bij het ontwerpen van taken aandacht moeten besteden aan het aanbieden van voldoende autonomie, sociale steun en ontwikkelingsmogelijkheden aan jonge werknemers, want deze hulpbronnen zijn cruciaal voor hun welzijn en prestaties.

- HR afdelingen, opleidingsmanagers en loopbaancoaches kunnen de nieuw ontwikkelde Career Competencies Questionnaire (CCQ) inzetten als monitoring tool en als diagnostisch instrument om bij (jonge) werknemers de ontwikkeling in hun loopbaancompetenties en inzetbaarheid te volgen.

- De CareerSKILLS-training is een effectieve groepsinterventie onder jonge werknemers om loopbaancompetenties, inzetbaarheid en bevlogenheid te versterken. Organisaties kunnen deze training opnemen in hun HR beleid als 'talent development tool'.

- Het integreren van kennis en beleid over werk (bijv. taakontwerp en welzijn) en loopbaan (bijv. loopbaancompetenties en inzetbaarheid) is een belangrijke stap voorwaarts om jonge werknemers een sterke basis voor duurzame inzetbaarheid te geven. Het ontwikkelen van 'smart jobs', waarmee organisaties en individuele werknemers productief en innovatief kunnen zijn, is daarvoor een veelbelovende richting.

\section{Literatuur}

Akkermans, J. (2013). Well begun is half done: Investigating the work and career of the young workforce. Enschede: Ipskamp Drukkers.

Akkermans, J., Brenninkmeijer, V., Blonk, R.W.B., \& Koppes, L.L.J. (2009). Fresh and healthy? Well-being, health and performance of young employees with intermediate education. Career Development International, 14, 671-699.

Akkermans, J., Brenninkmeijer, V., Huibers, M., \& Blonk, R.W.B. (2013a). Competencies for the contemporary career: Development and preliminary validation of the career competencies questionnaire. Journal of Career Development, 40, 245-267. 
Akkermans, J., Brenninkmeijer, V., Blonk, R.W.B., \& Schaufeli, W.B. (2015a). It's all about CareerSKILLS: Effectiveness of a Career Development Intervention for Young Employees. Human Resource Management, 54, 533-551.

Akkermans, J., Brenninkmeijer, V., Van den Bossche, S.M.J., Blonk, R.W.B., \& Schaufeli, W.B. (2013b). Young and going strong? A longitudinal study on occupational health among young employees of different educational levels. Career Development International, 18, 416-435.

Akkermans, J., \& Lagerveld, S. (2010). CareerSKILLS: Protocol van een interventie gericht op het versterken van loopbaancompetenties van jonge werknemers. Hoofddorp: TNO.

Akkermans, J., Nykänen, M., \& Vuori, J. (2015b). Practice makes Perfect? Antecedents and Consequences of an Adaptive School-to-Work Transition. In J. Vuori, R.W.B. Blonk, \& R. Price (Eds.), Sustainable Working Lives, Aligning Perspectives on Health, Safety, and Well-Being. London: Springer Publishers. doi: 10.1007/978-94-017-9798-6_5.

Akkermans, J., Schaufeli, W.B., Brenninkmeijer, V., \& Blonk, R.W.B. (2013c). The role of career competencies in the Job Demands-Resources Model. Journal of Vocational Behavior, 83, 356-366.

Anakwe, U.P., Hall, J.C., \& Schor, S.M. (2000). Knowledge-related skills and effective career management. International Journal of Manpower, 21, 566-579.

Arnold, J., \& Cohen, L. (2008). The psychology of careers in industrial and organizational settings: A critical but appreciative analysis. In G.P. Hodgkinson \& J.K. Ford (Eds.), International Review of Industrial and Organizational Psychology (pp. 1-44). Chichester: Wiley.

Arthur, M.B., Khapova, S.N., \& Wilderom, C.P.M. (2005). Career success in a boundaryless career world. Journal of Organizational Behavior, 26, 177-202.

Baltes, P.B., \& Baltes, M.M. (1990). Psychological perspectives on successful aging: The model of selective optimization with compensation. In P.B. Baltes \& M.M. Baltes (Eds.), Successful aging: Perspectives from the behavioral sciences (pp. 1-34). New York: Cambridge University Press.

Bandura, A. (1997). Self-efficacy: The exercise of control. New York: Freeman.

Bauer, T.N., Bodner, T., Erdogan, B., Truxillo, D.M., \& Tucker, J.S. (2007). Newcomer adjustment during organizational socialization: A meta-analytic review of antecedents, outcomes, and methods. Journal of Applied Psychology, 92, 707-721.

Borg, V., \& Kristensen, T.S. (2000). Social class and self-rated health: can the gradient be explained by differences in life style or work environment? Social Science and Medicine, 51, 1019-1030.

Brenninkmeijer, V., \& Blonk, R.W.B. (2011). The effectiveness of the JOBS program among the long-term unemployed: A randomized experiment in the Netherlands. Health Promotion International, 27, 220-229.

Caplan, R.D., Vinokur, A.D., Price, R.H., \& Van Ryn, M. (1989). Job-seeking, reemployment and mental health: A randomized field experiment in coping with job loss. Journal of Applied Psychology, 74, 759-769.

Colakoglu, S.N. (2011). The impact of career boundarylessness on subjective career success: The role of career competencies, career autonomy, and career insecurity. Journal of Vocational Behavior, 79, 47-59.

Crawford, E.R., LePine, J.A., \& Rich, B.L. (2010). Linking job demands and resources to employee engagement and burnout: A theoretical extension and meta-analytic test. Journal of Applied Psychology, 95, 834-848.

Day, R., \& Allen, T.D. (2004). The relationship between career motivation and self-efficacy with protégé career success. Journal of Vocational Behavior, 64, 72-91. 
De Cuyper, N., \& De Witte, H. (2008). Gepercipieerde kans op een baan versus een betere baan: relaties met arbeidstevredenheid en welzijn. Gedrag \& Organisatie, 21, 475-492.

Defillippi, R.J., \& Arthur, M.B. (1994). The Boundaryless Career: A competency-based perspective. Journal of Organizational Behavior, 15, 307-324.

De Lange, A.H., De Witte, H., \& Notelaers, G. (2008). Should I stay or should I go? Examining the longitudinal relation between job resources and work engagement for stayers versus movers. Work \& Stress, 22, 201-233.

Demerouti, E., Bakker, A.B., Nachreiner, F., \& Schaufeli, W.B. (2001). The Job DemandsResources model of burnout. Journal of Applied Psychology, 85, 499-512.

De Vos, A., De Clippeleer, I., \& Dewilde, T. (2009). Proactive career behaviors and career success during the early career. Journal of Occupational and Organizational Psychology, 82, 761-777.

European Commission. (2012). Employment and Social Developments in Europe 2011. Luxembourg: Publications Office of the European Union.

Eurostat. (2013). Statistics Explained. Category: Labour Market. Gedownload van: http://epp. eurostat.ec.europa.eu/statistics_explained/index.php/Category:Labour_market

Goodman, S.A., \& Svyantek, D.J. (1999). Person-organization fit and contextual performance: Do shared values matter. Journal of Vocational Behavior, 55, 254-275.

Goodwin, J., \& O'Connor, H. (2007). Continuity and change in the experiences of transition from school to work. International Journal of Lifelong Learning, 26, 555-572.

Hall, D.T., \& Las Heras, M. (2010). Reintegrating job design and career theory: Creating not just good jobs but smart jobs. Journal of Organizational Behavior, 31, 448-462.

Hall, D.T., \& Moss, J.E. (1998). The new protean career contract: Helping organizations and employees adapt. Organizational Dynamics, 26, 22-37.

Hobfoll, S.E. (1989). Conservation of resources: A new attempt at conceptualizing stress. American Psychologist, 44, 513-524.

Hobfoll, S.E. (2011). Conservation of resource caravans and engaged settings. Journal of Occupational and Organizational Psychology, 84, 116-122.

Holland, J.L. (1985). Making Vocational Choices. Englewood Cliffs, NJ: Prentice-Hall.

Kahn, L.B. (2010). The long-term labor market consequences of graduating from college in a bad economy. Labour Economics, 17, 303-316.

Koivisto, P., Vuori, J., \& Nykyri, E. (2007). Effects of the school-to-work group method among young people. Journal of Vocational Behavior, 70, 277-296.

Kong, H. (2013). Relationships among work-family supportive supervisors, career competencies, and job involvement. International Journal of Hospitality Management, 33, 304-309.

Koppes, L.L.J., De Vroome, E.M.M., \& Van den Bossche, S.N.J. (2010). The Netherlands working conditions cohort study. Hoofddorp: TNO.

Korunka, C., Kubicek, B., Schaufeli, W.B., \& Hoonakker, P. (2009). Work engagement and burnout: Testing the robustness of the Job-Demands Resources model. The Journal of Positive Psychology, 4, 243-255.

Kuijpers, M.A.C.T. (2003). Loopbaanontwikkeling. Enschede: Twente University Press.

Kuijpers, M.A.C.T., Meijers, F., \& Gundy, C. (2011). The relationship between learning environment and career competencies of students in vocational education. Journal of Vocational Behavior, 78, 21-30.

Kuijpers, M.A.C.T., \& Scheerens, J. (2006). Career competencies for the modern career. Journal of Career Development, 32, 303-319.

Kuijpers, M.A.C.T., Schyns, B., \& Scheerens, J. (2006). Career competencies for career success. The Career Development Quarterly, 55, 168-178. 
Lyons, S., \& Kuron, L. (2014). Generational differences in the workplace: A review of the evidence and directions for future research. Journal of Organizational Behavior, 35, 139-157.

Maxwell, K.A. (2002). Friends: The role of peer influence across adolescent risk behaviors. Journal of Youth and Adolescence, 31, 267-277.

Mayotte, G.A. (2003). Stepping stones to success: Previously developed career competencies and their benefits to career switchers transitioning to teaching. Teaching and Teacher Education, 19, 681-695.

McKee-Ryan, F.M., Song, Z., Wanberg, C.R., \& Kinicki, A.J. (2005). Psychological and physical well-being during unemployment: A meta-analytic study. Journal of Applied Psychology, 90, 53-76.

Meichenbaum, D. (1985). Stress inoculation training: A clinical guidebook. Elmsford, NY: Pergamon Press.

Mirvis, P.H., \& Hall, D.T. (1994). Psychological success and the boundaryless career. Journal of Organizational Behavior, 15, 365-380.

Nieuwenhuis, L., Coenen, J., Fouarge, D., Harms, T., \& Oosterling, M. (2012). De creatie van publieke waarde in het middelbaar beroepsonderwijs. Gedownload van: http://www. nwo.nl/files.nsf/pages/NWOP_8YRECJ/\$file/PubliekewaardevanhetMBO.pdf

Ng, T.W.H., Sorensen, K.L., \& Eby, L.T. (2006). Locus of control at work: A meta-analysis. Journal of Organizational Behavior, 27, 1057-1087.

Ouweneel, A.P., Taris, T.W., Van Zolingen, S.J., \& Schreurs, P.J. (2009). How task characteristics and social support relate to managerial learning: empirical evidence from Dutch home care. The Journal of Psychology, 143, 28-44.

Polat, T. (2015). Active aging in work: Motivating employees to continue working after retirement. Amsterdam: Amsterdam Business Research Institute (ABRI).

Raad voor Werk en Inkomen. (2011). Arbeidsmarktanalyse 2011. Raad voor Werk en Inkomen.

Ryan, P. (2001). The school-to-work transition: a cross-national perspective. Journal of Economic Literature, 39, 34-92.

Savickas, M.L. (2005). The theory and practice of career construction. In S.D. Brown \& R.W. Lent (Eds.), Career development and counseling: Putting theory and research to work (pp. 42-70). Hoboken, NJ: John Wiley \& Sons.

Schaufeli, W.B., \& Bakker, A.B. (2004). Job demands, job resources, and their relationship with burnout and engagement: A multi-sample study. Journal of Organizational Behavior, 25, 293-315.

Scherer, S. (2004). Stepping stones or traps? The consequences of labor market entry positions on future careers in West Germany, Great Britain, and Italy. Work Employment and Society, 18, 369-394.

Segers, J., \& Inceoglu, I. (2012). Exploring supportive and developmental career management through business strategies and coaching. Human Resource Management, 51, 99-120.

Smulders, P.G.W. (2005). Jongere en oudere werknemers: hun werk, werktijden, ongevallen en verzuim. Hoofddorp: TNO.

Spector, P.E., Cooper, C.L., Sanchez, J.I., O’Driscoll, M., \& Sparks, K. (2002). Locus of control and well-being at work: How generalizable are western findings? Academy of Management Journal, 45, 453-466.

Tims, M., Bakker, A.B., \& Derks, D. (2013). De Job Demands-Resources benadering van job crafting. Gedrag \& Organisatie, 26, 16-31. 
Vinokur, A.D., Price, R.H., \& Schul, Y. (1995). Impact of the JOBS intervention on unemployed workers varying in risk for depression. American Journal of Community Psychology, 23, 39-74.

Vuori, J., Toppinen-Tanner, S., \& Mutanen, P. (2011). Effects of resource-building group intervention on career management and mental health in work organizations: Randomized controlled field trial. Journal of Applied Psychology, 97, 273-286.

Xanthopoulou, D., Bakker, A.B., Demerouti, E., \& Schaufeli, W.B. (2007). The role of personal resources in the Job Demands-Resources Model. International Journal of Stress Management, 14, 121-141.

Xanthopoulou, D., Bakker, A.B., Demerouti, E., \& Schaufeli, W.B. (2009). Reciprocal relationships between job resources, personal resources, and work engagement. Journal of Vocational Behavior, 74, 235-244.

\section{Bijlage 1 de Career Competencies Questionnaire (CCQ)}

De volgende stellingen gaan over de ontwikkeling van je loopbaan: je werk in het heden en in de toekomst. Geef bij elke stelling aan in hoeverre je het hiermee eens bent.

\section{Tabel 1}

\begin{tabular}{|c|c|c|c|c|c|}
\hline & I & 2 & 3 & 4 & 5 \\
\hline & $\begin{array}{l}\text { Helemaal } \\
\text { mee } \\
\text { oneens }\end{array}$ & $\begin{array}{l}\text { Mee } \\
\text { oneens }\end{array}$ & Neutraal & Mee eens & $\begin{array}{l}\text { Helemaal } \\
\text { mee eens }\end{array}$ \\
\hline $\begin{array}{l}\text { Ik weet wat ik leuk vind in } \\
\text { mijn werk. }\end{array}$ & I & 2 & 3 & 4 & 5 \\
\hline $\begin{array}{l}\text { Ik weet wat voor mij } \\
\text { belangrijk is in mijn loop- } \\
\text { baan. }\end{array}$ & I & 2 & 3 & 4 & 5 \\
\hline $\begin{array}{l}\text { Ik heb duidelijk voor ogen } \\
\text { wat mijn passies zijn. }\end{array}$ & I & 2 & 3 & 4 & 5 \\
\hline $\begin{array}{l}\text { Ik weet wat mijn sterke } \\
\text { punten zijn in mijn werk. }\end{array}$ & I & 2 & 3 & 4 & 5 \\
\hline $\begin{array}{l}\text { Ik ken mijn eigen beperkin- } \\
\text { gen in mijn werk. }\end{array}$ & I & 2 & 3 & 4 & 5 \\
\hline $\begin{array}{l}\text { Ik ben me bewust van mijn } \\
\text { talenten in mijn werk. }\end{array}$ & I & 2 & 3 & 4 & 5 \\
\hline $\begin{array}{l}\text { Ik weet over welke vaardig- } \\
\text { heden ik beschik. }\end{array}$ & I & 2 & 3 & 4 & 5 \\
\hline $\begin{array}{l}\text { Ik ken veel mensen binnen } \\
\text { mijn werk die mij kunnen } \\
\text { helpen met mijn loopbaan. }\end{array}$ & I & 2 & 3 & 4 & 5 \\
\hline $\begin{array}{l}\text { Ik ken veel mensen buiten } \\
\text { mijn werk die mij kunnen } \\
\text { helpen met mijn loopbaan. }\end{array}$ & I & 2 & 3 & 4 & 5 \\
\hline $\begin{array}{l}\text { Ik weet hoe ik mensen in } \\
\text { mijn netwerk om hulp kan } \\
\text { vragen. }\end{array}$ & I & 2 & 3 & 4 & 5 \\
\hline
\end{tabular}


Tabel $1 \quad$ (Vervolg)

\begin{tabular}{|c|c|c|c|c|c|}
\hline & I & 2 & 3 & 4 & 5 \\
\hline & $\begin{array}{l}\text { Helemaal } \\
\text { mee } \\
\text { oneens }\end{array}$ & $\begin{array}{l}\text { Mee } \\
\text { oneens }\end{array}$ & Neutraal & Mee eens & $\begin{array}{l}\text { Helemaal } \\
\text { mee eens }\end{array}$ \\
\hline $\begin{array}{l}\text { lk kan de juiste mensen } \\
\text { benaderen om mij te hel- } \\
\text { pen met mijn loopbaan. }\end{array}$ & I & 2 & 3 & 4 & 5 \\
\hline $\begin{array}{l}\text { Ik kan duidelijk aan anderen } \\
\text { laten merken waar ik goed } \\
\text { in ben in mijn werk. }\end{array}$ & I & 2 & 3 & 4 & 5 \\
\hline $\begin{array}{l}\text { Ik ben in staat aan mensen } \\
\text { duidelijk te maken wat ik } \\
\text { wil bereiken in mijn loop- } \\
\text { baan. }\end{array}$ & I & 2 & 3 & 4 & 5 \\
\hline $\begin{array}{l}\text { Ik kan aan mijn omgeving } \\
\text { laten zien wat ik belangrijk } \\
\text { vind in mijn werk. }\end{array}$ & I & 2 & 3 & 4 & 5 \\
\hline $\begin{array}{l}\text { Ik weet hoe ik mogelijkhe- } \\
\text { den kan onderzoeken die } \\
\text { er voor mij zijn om me ver- } \\
\text { der op te laten leiden. }\end{array}$ & I & 2 & 3 & 4 & 5 \\
\hline $\begin{array}{l}\text { Ik kan zoeken naar de ont- } \\
\text { wikkelingen binnen mijn } \\
\text { vakgebied. }\end{array}$ & I & 2 & 3 & 4 & 5 \\
\hline $\begin{array}{l}\text { Ik ben in staat om de } \\
\text { mogelijkheden te verken- } \\
\text { nen die er voor mij zijn op } \\
\text { de arbeidsmarkt. }\end{array}$ & I & 2 & 3 & 4 & 5 \\
\hline $\begin{array}{l}\text { Ik kan duidelijke plannen } \\
\text { maken voor mijn loopbaan. }\end{array}$ & I & 2 & 3 & 4 & 5 \\
\hline $\begin{array}{l}\text { Ik weet wat ik over een } \\
\text { jaar bereikt wil hebben in } \\
\text { mijn loopbaan. }\end{array}$ & I & 2 & 3 & 4 & 5 \\
\hline $\begin{array}{l}\text { Ik weet hoe ik een planning } \\
\text { maak voor wat ik wil berei- } \\
\text { ken in mijn loopbaan. }\end{array}$ & I & 2 & 3 & 4 & 5 \\
\hline $\begin{array}{l}\text { Ik kan voor mezelf doelen } \\
\text { stellen die ik wil bereiken in } \\
\text { mijn loopbaan. }\end{array}$ & I & 2 & 3 & 4 & 5 \\
\hline
\end{tabular}

NB Item I-3 = reflectie op motivatie; item 4-7 = reflectie op kwaliteiten; item 8-II = netwerken; item I2-14 = zelf-profilering; item I5-17 = werkexploratie; item $18-2 \mid$ = loopbaansturing.

De Vragenlijst Loopbaancompetenties mag vrij gebruikt worden voor niet-commerciële wetenschappelijke doeleinden. Het is verboden om, zonder schriftelijke toestemming vooraf van de auteur, de vragenlijst te gebruiken voor commerciële en/of niet-wetenschappelijke doelstellingen. 


\section{A new perspective on the work and career of young employees}

Jos Akkermans, Veerle Brenninkmeijer \& Roland W.B. Blonk, Gedrag \& Organisatie, Volume 28, September 2015, nr. 3, pp. 220-242.

This article provides an overview of our research on the well-being and career development of young employees who are about to make, or have recently made, the transition from school to work. We discuss our findings with regard to the job characteristics that are important for enabling young adults to perform well, and with regard to the career competencies they need to have a successful start in their working lives. We show that it is of particular importance to integrate research on well-being and career development among young workers. Moreover, we have developed and empirically tested two tools: the Career Competencies Questionnaire (CCQ) and the CareerSKILLS intervention. This article presents these tools and also offers a number of recommendations for future research and for practice.

Key words: young workers, career competencies, employability, well-being, job design 